\title{
Strategic Approach to Goal Achievement in Ancient Jain Literature: Rediscovered in Sthananga Sutra
}

\author{
Dr. Alka Jain \\ Assistant Professor cum Placement Officer, S.S. Jain Subodh Management Institute, Jaipur
}

\begin{abstract}
The study displaysstrategic approach to goal achievement with an excellent insight into code of conduct of a Jain follower's behavior, where Jain community acts as an organization.It is a well-known fact that achieving goals is important to meet long-term objectives, whatever be the structure and goal of the organization. No matter whether it is a profitable organization like a business unit or a non-profit or religious organization, goal achievement is equally significant for all kinds of organizations. The author has rediscovered Jaina way of managing goal achievement and it has been found that 2500 years ago also the Jain community was managing their religious goal achievement with a strategic approach. That ancient strategic approach is relevant for modern businesses also and if implemented appropriately, it can lead to a speedy long term goal achievement with short term goals being used as steps of a ladder to the goal. The Jaina scripture 'Sthananga Sutra' speaks about various dimensions of this strategic approach -In verses 538 to 540, degrees of goal achievements and continuums to measure goal achievement are provided. Scope of the research is an ancient Jain book - Sthananag Sutra and observation of code of conduct of Jain followers. All the types of tapa penance chains(likeKanakawali, Ratnavali, sarvatobhadra or Mahasaravatobhadra etc. mentioned in HarivanshPurana and Uttradhyayana Sutra.) are strategies to achieve the goal of Moksha and karma eradication. Under formulation of goal achievement strategy, factors like assessment of environment, creation of vision, setting measureable objectives, executing the strategy and controlling and evaluating the entire process are considered.
\end{abstract}

Keywords: Goal achievement, Goal setting, Ancient literature, Jain literature, Strartegic approach, Sthananga Sutra, managing goal achievement

\section{Research Questions}

1. Does the ancient Jain scripture ,Sthanangaee deal with target and goal achievement?

2. Is Jain approach to goal achievement strategic by nature?

3. Is this approach useful in goal achievement of modern businesses?

\section{Objective}

With the help of above research questions in mind, the objective of this study is to analyseJaina theory of goal achievement. "Mokshae in Jain community is the ultimate goal. The comparison of Jaina approach with modern goal achievement theories may prove the relevance of ancient Sthanangaatrategic approach in modern managerial world.

\section{Methods and Materials}

To conduct this research, a comparative study of modern Goal Achievement Theories and ancient Jain theory has been done. English and Hindi translations of Sthananga Sutra by Shri Amar Muni and Acharya AbhayadevSuri are used for analysis of ancient Jaina theory of goal achievement. Modern theories have been studied from various management books and journals. The great book „Sthananga ${ }^{e e}$ provides us with relevant ideas of successful management of goal achievement, which if used in modern businesses will surely lead to speedy goal achievement and improved business productivity of the world economy.

\section{SthanangaSutra: An introduction}

The great book ,Sthananga ${ }^{e e}$ is divided into ten chapters, each chapter giving classifications of various subjects/objects as per the numbering of its chapter. Through these classifications of subjects and objects, we get a glimpse of high intellect of the creator of this book. According to Pravartaka Amar muni - A renowned Jain saint, "With its unique numerical style of compilation, Shri Sthananga Sutra is an important compendium of knowledge and information. In erudite aphoristic style it envelopes a variety of subjects including metaphysics, philosophy, code of conduct, astrology, cosmology, mathematics, ethics, and vivid analogical presentation of human psyche. All these subjects are edifying as well as useful in life." The book explains its philosophy through a brief combination of words- called sutras. The author has analyzed a few sutras to discover continuum theory of leadership in ancient India.

\section{What is Goal Achievement?}

Psychological interpretation of goal achievement: 'Individuals have a 'personal theory' about what achievement means to them for that specific situation or task. The characteristics of the situation and task interact to impact the state of the goal the individual adopts.....Achievement behaviour is "the behaviour in which the goal is to develop or demonstrate to self and others high ability or avoid demonstrating low ability". Ability is constructed in two ways. Firstly, ability can be judged high or low with reference to the individual's own past performance or knowledge. In this context, gains in mastery indicate competence. Secondly, to demonstrate high capacity, one must achieve more with equal effort or use less effort than others do for an equal performance." Another scholar has defined the term goal achievement in beautiful philosophic words, "Goals are dreams with deadlines."Focus on self- achievement leads towards higher productivity of a person and consequently of the organization, he/she is 


\section{International Journal of Science and Research (IJSR) \\ ISSN (Online): 2319-7064 \\ Index Copernicus Value (2013): 6.14 | Impact Factor (2014): 5.611}

associated with. Proper management of goal achievement handles complicated issues in productivity.

According to Richard Hale and Peter Whitlam "Goals, targets and objects are ideal ways to stretch individuals and develop an organization. A common misconception however is that it is very difficult, if not impossible, to set targets for certain jobs and roles. Firmly based on leading-edge research, yet highly practical in focus,Target Setting and Goal Achievement shows how it is possible to set targets in all functions of an organization and in all sectors. Clear guidelines are supported by real examples and detailed case studies as the authors outline step-by-step advice to help:"

\section{Goal Achievement in Jain Philosophy}

Ultimate goal of all activities of a Jain follower is supposed to be ,Moksha ${ }^{e e}$ - the supreme liberation. Jain literature is focused on explaining the methods of attaining Moksha by eradicating all karmaload leading to birth and death cycle of a soul. Extracts from Sthanang Sutra explain how to identify individual standards (in terms of tapa, code of conduct etc.), discover how one can utilize and improve these self-limiting patterns of behavior for speedy goal achievement.This outlook sets some realistic short-term goals (in terms of punya etc.)and objectives (Karma eradication, shubh karma collection) for a speedy goal - attainment of moksha.

\section{,अपध्वंसपद'Sutra 566 : Self Analysis before Goal Setting \\ "चउविहाअवद्धँसेपण्णत्ते , तंजहा - आसुरे, आभिओगे, संमोहे, देवकिव्विसे]" \\ अपध्वंस(decline) is of four kinds - 1.Asura apadhwansa (decline) 2. Aabhiyogaapadhwansa (decline) 3. Sanmohaapadhwansa (decline) 4. Devkilvishapadhwansa (decline)}

Commentary of this verse "Austerities observed with spiritual purity lead to liberation and those done with pious feelings lead to birth in higher divine ralms. But austerities connected with some aspirations or desire of attainments , although lead to birth in divine realm but of lower levels. The rituals and conduct that lead to Asuri realm are included in AsuriBhaavana attitude The rituals and conduct that lead to birth as Aabhiyogik Gods are included in AabhiyogiBhaavana. The rituals and conduct that lead to Sammohak Gods are included in SammohakBhaavana. The rituals and conduct that lead to Kilvish Gods are included in Devkilvishibhaavana.In fact all these four bhavnas cause moral decline and therefore they are included here as four kinds of decline.Even while observing ascetic conduct an aspirant gets destined to birth as a lower God depending on the sentiment he is involved in.

\section{Sutra 538 :Fruits of goal achievement (AmbaPitruPada) "चत्तारिमेहापण्णत्ताजणइत्ताणाममेगेणोणिम्मवइत्ता, णिम्मवइत्ताणाममेगेणोजणइत्ता, एगेजणइत्ताविणिम्मवइत्तावि , एगेणोजणइत्ताणोणिम्मवइत्ता]] \\ Clouds are of four kinds - Some clouds cause sprouting of grain but do not cause ripening. Some clouds help in ripening but not in sprouting, some clouds sprout and help in ripening also, some clouds neither help in sprouting the seeds nor in ripening. \\ Further this verse has been interpreted by Amar Muni Shree for social benefits. He says," Some parents give birth to the}

child but do not bring up a child by feeding, nursing and educating, some parents bring up the child but do not give birth to the child, some parents give birth and bring up also while some parents neither give birth nor bring up the child. The study contributes to draw our attention to a few sutras of Sthanang Sutra which are an evidence of theoretical development of Goal Achievement Theory in the glorious past of Ancient India.

\section{Sutra 539: Coverage of goal achievement “चत्तारिमेहापण्णत्ता, \\ तंजहा - देसवासीणाममेगेणोसव्ववासी, सव्ववासीणाममेगेणोदेसवासी, \\ एगेदेसवासीविसव्ववासीवि, एगेणोदेसवासीणोसव्ववासी] \\ एवाम्मेक्सचत्तारिरायाणोपण्णत्ता, तंजहा - देसाधिवतीणाममेगेणोसव्वाधिवती, सव्वाधिवतीणाममेगेणोदेसाधिवती, एगेदेसाधिवतीवीसव्वाधिवतीवि ,} एगेणोदेसाधिवतीवीणोसव्वाधिवतीवि] 539"

This sutra hints at a manager's behavior towards employees, when four types of clouds are explained -1 . Some clouds rain in a specific area but do not rain in all states or in a very wide area 2. This type rains in all states and not in a specific area. 3. Some clouds rain in a specific area also and in all states also 4. Some clouds neither rain in a specific area nor in all states. In fact this categorization is further elaborated to explain four kinds of kings in that era : 1 . One who rules in a specific state and not all states 2 . One who rules in all states and not a particular state 3 . Some kings rule a specific region also and all states also (Chakravarti) 4. This type of king rules neither a state nor all states (A dethroned king)

\section{Sutra 540: Scope of Goal Achievement \\ "चत्तारिमेहापण्णत्ता- पुक्खलसंवट्टए, पज्जुण्णे, जीमूते, जिम्हे] \\ पुक्खलसंवट्टएणंमहामेहेएगेणंवासेणंदसवाससहस्साइंभावेति] \\ पज्जुण्णेणंमहामेहेएगेणंवासेणंदसवाससयाइंभावेति] \\ जीमूतेणंमहामेहेएगेणंवासेणंदसवासाइंभावेति], \\ जिम्हेणंमहामेहेबहूहिंवासेहिएगंवासंभावेतिवाणंवाभावेति $] 540$}

Clouds are said to be of four types: 1. this type of cloud makes the land fertile with just one rain for ten thousand years 2 . With just one rain this cloud makes the land fertile for one thousand years. 3 . With just one rain, it makes the land fertile for ten years 4 . With numerous rains it may or may not make the land fertile."

The commentator Pravartaka Amar Muni Jib informs that, like clouds the aforesaid quad should be applied to men. Hence, when we apply this continuum to modern managerial management, we observe that fertility is meant for productivity and rain is taken for communication of a leader with his followers. The sutra explains two extremes of a manager/leader where his motivational traits increase the productivity of an employee. This continuum is in fact continuously shown in these sutras. In this sutra effect of training/teachings/scolding/counselling etc. which is given by a manager to an employee is studied. This is compared to a cloud and the effect of its rains.

\section{Sutra 588 : Levelsof goal setting and achievements}

"चत्तारितरगापण्णत्ता , तंजहा - समुद्दतररामीतेगेसमुद्दुतरति , समुद्दंतरामीतेगेगोप्पयंतरति, गोप्पयंतरामीतेगेसमुद्दंतरति, गोप्पयंतरामीतेगेगोप्पयंतरति]

Swimmers are of four kinds -1 . Some swimmer resolves to cross a sea and actually swims it, 2 . Some swimmers resolve to swim a sea but actually swims a small water body or pond, 3 . Some swimmers resolve to cross a sea and cross the

\section{Volume 4 Issue 11, November 2015}




\section{International Journal of Science and Research (IJSR) \\ ISSN (Online): 2319-7064 \\ Index Copernicus Value (2013): 6.14 | Impact Factor (2014): 5.611}

sea 4. Some swimmers resolve to swim a pond and actually swim a pond only.

\section{Sutra 589 : Feedback after goal achievement \\ "चत्तारितरगापण्णत्ता , तंजहा - - समुद्दुतरेत्ताणाममेगेसमुद्देविसीयति, समुद्द्तरेत्ताणाममेगेगोप्पयंविसीयति, गोप्पयंतरेत्ताणाममेगेसमुद्देविसीयति,}

गोप्पयंतरेत्ताणाममेगेगोप्पएविसीयति

Swimmers are of four kinds -1 . After crossing a sea once, one gets dejected to cross a sea again 2. After crossing a sea once, one gets dejected to cross a pond again, 3. After crossing a pond once, one gets dejected to cross a sea again 4. After crossing a pond once, one gets dejected to cross a pond again.

\section{Strategy Formulation of Goal Achievement in Jain \\ Philosophy}

- Step 1. The saadhaka grows and advances to the next level by achieving objectives that are determined by a strategic planning process.

- Step 2. The next step is figuring out a way to break annual goals down into sizable tasks that can be incorporated into daily activities. Let's look at this graphic as an example.

- Step 3 . Figure out the status of a person's performance, once he/she achieves a set target and assign tasks accordingly in future.

\section{Strategic Management of Goal Achievement in Jain and Modern Theories}

Comparison between Modern and Sthananga Goal Achievement Theory

Important factors according to „Goal Achievement Congruence Model $^{\text {ee }}$ are :

a) Goal Clarity - The ultimate goal of life is ,Mokshaee

b) View of Possibilities - By taking birth inMahavidehakshetra

c) Values - Strict code of conduct

d) Achievement Drive - Jain Diksha and life of a saint

e) Supportive Environment - The ascetic teachers and family (singhada) of nuns and monks create an environment that supports their way of life.

All the above factors are discussed in Sthananga Goal Achievement theory.

\begin{tabular}{|c|c|c|}
\hline $\begin{array}{c}\text { Goal } \\
\text { appraisal }\end{array}$ & $\begin{array}{c}\text { Performance appraisal in Jain } \\
\text { Goal Achievement } \\
\text { Management }\end{array}$ & $\begin{array}{c}\text { Performance } \\
\text { appraisal in } \\
\text { Modern Goal } \\
\text { Achievement } \\
\text { Management }\end{array}$ \\
\hline $\begin{array}{c}\text { Annual } \\
\text { Goals }\end{array}$ & SamwatsarikPratikraman & $\begin{array}{c}\text { Annual General } \\
\text { meetings and } \\
\text { appraisals }\end{array}$ \\
\hline $\begin{array}{c}\text { Monthly } \\
\text { Goal }\end{array}$ & $\begin{array}{c}\text { Twice in a month with } \\
\text { Pakshikpratikraman }\end{array}$ & $\begin{array}{c}\text { Monthly meetings } \\
\text { and appraisals }\end{array}$ \\
\hline Daily \\
Task List & $\begin{array}{c}\text { Strict Jaina code of conduct } \\
\text { and day/night pratikraman }\end{array}$ & $\begin{array}{c}\text { Analysis of daily } \\
\text { targets through } \\
\text { routine activities }\end{array}$ \\
\hline
\end{tabular}

One beautiful quality of Jaina Goal Achievement Theory is taking great goals and breaking them into small actionable steps facilitates accomplishing goals one small step at a time and eliminates the stress of trying to accomplish many steps all at once.
Elements of Goal Achievement Management Process

\begin{tabular}{|c|c|c|c|c|}
\hline Elements & $\begin{array}{c}\text { Identify } \\
\text { individual } \\
\text { standards }\end{array}$ & $\begin{array}{c}\text { Discovery of } \\
\text { improvement } \\
\text { tools }\end{array}$ & $\begin{array}{l}\text { Realistic } \\
\text { short term } \\
\text { goals }\end{array}$ & Objectives \\
\hline & $\begin{array}{l}\text { Capacity to do } \\
\text { tapa etc. }\end{array}$ & $\begin{array}{l}\text { In terms of } \\
\text { tapa and code } \\
\text { of conduct }\end{array}$ & Punya & $\begin{array}{c}\text { Eradication } \\
\text { of karma }\end{array}$ \\
\hline & $\begin{array}{l}\text { Capacity to } \\
\text { perform in the } \\
\text { organization }\end{array}$ & $\begin{array}{l}\text { In terms of } \\
\text { performance }\end{array}$ & $\begin{array}{l}\text { Higher } \\
\text { salary, } \\
\text { promotion, } \\
\text { incentives }\end{array}$ & $\begin{array}{c}\text { Long and } \\
\text { respectable } \\
\text { stay in } \\
\text { organization } \\
\text { with } \\
\text { improved } \\
\text { business } \\
\text { productivity }\end{array}$ \\
\hline
\end{tabular}

\section{Conclusion}

The study attempts to present many different results in a unified framework, which will familiarize modern management scholars with ancient strategic approach to goal achievement discussing various important dimensions. This study will surely attract modern scholares attention towards this valuable treasure of management, which is stored in the form of Jaina scriptures with various sects of Jain community.

\section{Limitations of the Study}

- The theories rediscovered from Jain scriptures were developed for spiritual goal- Moksha which are to be generalised for materialistic goals- organisational goal.

- The terminology used in ancient literature has to be interpreted in modern words and ideas in order to make it relevant for modern readers and management practitioners.

\section{Glossary}

1) Pratikraman: A Jain ritual performed to criticize one own ill deeds

2) SamwatsarikPratikraman : yearly pratikraman ritual

3) Pakshik : Fortnightly pratikraman ritual

\section{References}

[1] Pravartaka Amar Muni, ,Illustrated Sthananga Sutra Part II ${ }^{\mathrm{e}}$, Padma Prakashan, Delhi, 2004.

[2] Acharya AbhayadevSuri, „Shri Sthananga Sutra dwiteeyavibhago"e, Shri Mahavira Jain Vidyalaya, Mumbai, 2003.

[3] Donnelley, Gibson, Ivancevich, „Fundamentals of Managemente, Business Publications Inc.,United States of America, 1987.

[4] Gary Dessler, „Management Fundamentals"e, Reston Publishing Company Inc, Virginia, 1985.

[5] Target Setting and Goal Achievement: A Practical Guide for Managers, Richard Hale, Peter Whitlam, Kogan Page Publishers, 1998

[6] Madhukar Muni, „Uttaradhyayana Sutra ${ }^{e e}$ Shree AagamprakashanSamiti, Beawar, Rajasthan,India, 1984. 


\section{International Journal of Science and Research (IJSR) \\ ISSN (Online): 2319-7064}

Index Copernicus Value (2013): 6.14 | Impact Factor (2014): 5.611

[7] Nalini V. Dave, „Vedanta and Management ${ }^{\circ} p$ p 48-66,98-

120,Deep \& Deep Publications Pvt Ltd., New Delhi

2001.

Volume 4 Issue 11, November 2015

www.ijsr.net 